\section{Research Article}

(C) 2022 Bozheku et al. This is an open access article licensed under the Creative Commons Attribution-NonCommercial 4.o International License (https://creativecommons.org/licenses/by-nc/4.o/)

\title{
Theoretical-Conceptual, Legal and Social Problems of the Albanian Criminal Code: Some Useful Observations in view of its Reform
}

\author{
Ersi Bozheku \\ Professor of Criminal Law at the Doctoral School of Public Law, \\ Faculty of Law, Sapienza University of Rome, \\ Piazzale Aldo Moro, 5, 00185 , \\ Roma RM, Italy \\ Enida Bozheku \\ Lecture of International Criminal Law, \\ Faculty of Law, Luarasi University of Tirana, \\ Rruga Dritan Hoxha 127/1, \\ Tirana, 100o, Albania

\section{Klodian Skënderaj} \\ Professor of Criminal Procedure Law, \\ Faculty of Law, University of Tirana, \\ Rruga Milto Tutulani, \\ Tirana, 100o, Albania
}

DOI: https://doi.org/10.36941/ajis-2022-0053

\section{Abstract}

The problems of the Albanian criminal code are many and of different nature. In this short article, only some of the main issues will be highlighted, by underlying the most critical issues, while - for obvious reasons of space - individual institutes will not be explored in detail. We will try to carry out a general examination to understand what are the gaps, problems and possible solutions in view of a reform. In this regard, in fact, some elements will be highlighted that are believed to be of help to the ministerial commission that will be invested in the preparation of the new text.

Keywords: Criminal law, problematics, method, reform, Criminal code, general theory of crime, constitutional principles of criminal law, legal goods and criminal law

\section{Introduction}

The last few years have highlighted a strong reform movement in the Republic of Albania, with the aim of justice reform. Here, we do not want to retrace the reasons and the problems that led to the same. It is a fact, however, that 2016, saw an epochal moment that culminated with the constitutional reform (Bozheku, 2016). In particular, there has been a series of interventions that aimed at 
improving the judicial framework of the country (Agaci, 2017).

The structure of many key institutions for justice in the country has been modified, such as the High Court, the system of governance of the judiciary, with the establishment of new and unprecedented institutions, such as the Commission for the Evaluation of the Career of Magistrates (Spangher, 2017), or the Public Prosecutor's Office responsible for corruption and organized crime offenses. In fact, it is also thanks to a series of procedural facilitations that have been attributed to recent constitutional reforms (Bogdani, 2017).

As part of a 36o-degree reform strategy, it was considered appropriate to change not only the laws governing the functioning of the justice bodies, but also those of direct impact for citizens. In fact, a massive modification of the criminal procedure code was carried out. New figures have been included within it, such as the Judge for Investigations or the Judge for the Preliminary Hearing. Many procedural provisions have been revised regarding judgment before the High Court (Bozheku, 2016). The competences between the various judicial bodies of criminal justice have been modified and revised, including the most incisive one concerns the competences of the Court and the Prosecutor's Office against corruption and organized crime.

Alongside these interventions, the reform of the Albanian criminal code is awaited with great curiosity. Unlike the criminal procedure code (Liguori - Hoxha, 2017), it was considered more appropriate to proceed with a complete reform of the same and therefore with the replacement of the current text with a new one.

Moreover, the current criminal code has proved to be totally inadequate to respond to the needs of citizens' justice. The same suffers from many shortcomings. On the methodological level, there are several inconsistencies, which are a consequence of the erroneous approach taken at the time of its implementation. The code has not, however, had better luck even on the academic level. Very few are the works that have dealt in depth with his analysis (Bozheku, 2014). The academic examination is mostly descriptive rather than analytic. In fact, there is a lack of in-depth criticism concerning its limits and problems, just as there is a lack of solutions for the latter on an interpretative level. And indeed, the Albanian criminal code of 1995 has never grown and has never found intellectual support, in terms of correct interpretative and dogmatic methodological reconstruction by the doctrine or jurisprudence of the Supreme Court.

\section{Research Method}

The analysis that will be carried out is based on a study that dates back to 2007 and which has seen in all these years a continuous and careful critical analysis of the Albanian criminal code.

In this paper, attention will be focused on the main problems of the current criminal code to understand the reason for its failure. In a second part, the contribution will focus on the pivotal moments on which the reform should be focused. We will therefore try to give indications, which hopefully will be useful, so that the new text is truly in line with the cardinal principles of modern criminal law as well as with the principles expressed by the Constitution and the European Convention on Human Rights.

\section{The Inspiring Lines of the Current Criminal Code}

The Albanian criminal code was promulgated on January 27, 1995. It marks an important moment in the history of the country: it is the first criminal code of the post-communist era. Its value is certainly undeniable as it strives to break, at least on paper, the links with the Communist code of 1977 (Pittaro, 2006).

It is a code that opens up a new era. And this is easily understood only by observing that the real instrument of terror, indeed the instrument, on which totalitarian systems were based was precisely in the criminal code. Moreover, the use of elements extraneous to the liberal principles of criminal law such as analogy or the so-called Tatertyp (normative type of the author) characterized 
the criminal systems of Nazi Germany in the 1930 and the communist countries. This has clearly paved the way for the affirmation of the dictatorships that recent history has given us.

Beyond the ideological strength, certainly of appreciable depth, the 1995 Albanian criminal code betrayed its expectations: it cannot define itself as a well-made or modern code. There are many problems and many obscure points that certainly reduce its innovative strength. The aspect that suffers most is that inherent in a careful and in-depth dogmatic reflection, a circumstance that led to the creation of a work with highly contradictory profiles.

More than an organic law capable of regulating an entire discipline in a systematic and coherent way, the general part of the criminal code looks more like a mixture of provisions of the Italian, French and German criminal codes, without lacking provisions, such as mediation, typical of the systems of northern Europe (Bozheku, 2014). Eventually, it is precisely this cocktail of heterogeneous legal experiences that is perhaps the most critical point of the code.

The special part seems to refer, at least as regards the contents of the individual provisions, to the French code, even if unlike the latter the crimes are not divided into crimes, offenses and fines, but only between crimes and fines and the latter they are the prerogative of the parliament and not of the executive. According to the interpretation - however very debatable - given by the Albanian Constitutional Court for the approval of the criminal provisions, a quorum of three-fifths of the Parliament is requested.

\section{The Will to Break with the Past and Socio-Cultural Resistances}

Certainly the 1995 code has the advantage of wanting to break with the past not only symbolically but also conceptually. However, practical experience has shown that the simple modification of a text of law cannot produce the desired effects if not accompanied by a profound social and cultural reform. And perhaps this is precisely the main problem of the current code.

Many of the problems of the Albanian criminal code are closely linked with its inability to respond adequately to the social context. Proof of this is the fact that neither jurisprudence nor doctrine have been able to respond to the dogmatic and hermeneutic challenges that the current code proposes. And it is precisely at this moment that its failure is found and decreed. A code unable to be metabolized in its deeper contents by the protagonists of the justice system highlights its total inability and inadequacy in relation to the reference cultural context.

Yet the criminal code represents the highest expression of civilization and degree of cultural development of a given society at a given historical moment. This is because the criminal code contains and guarantees (but it would be more correct to say: it aims to guarantee) the highest values of a society, thus becoming the spokesperson for its needs. The main mission of a criminal code is, therefore, the protection of the values that the society considers fundamental for its own peaceful development and realization. The protection of the founding values of a society through the legal instrument, especially if it is a criminal one, guarantees its social peace by promoting its progressive emancipation.

There is, however, a fact that cannot escape this reasoning: it is up to the legislator to derive the cardinal values of the society and then translate them into rules, especially of a criminal law nature, which aims at the society protection. To this end, it is appropriate to encourage continuous dialogue with the protagonists of the society rather than resorting to the search for external (or foreign) models. This might be due to the fac that externally induced criminal code, which is therefore not the result of a academic legal discussion of the socio-cultural context of a country, could not achive the wanted results. And in this context, the Albanian criminal code probably constitutes the prototype of an unsuitable legislative instrument.

The faults of this failure cannot be identified only in the legislator, but, if anything, in a plurality of factors. Certainly, the legislator can be attributed to the fact that he wanted to solve the problem, whose source is primarily cultural: changing the laws we can also change the way people live and interpret reality. 
However, alongside its failure must also be ascribed that of an entire class of jurists and academics, unable to renew themselves and therefore to propose a valid technical interpretative system consistent with the new political and social reality. Above all, these have not been able to propose an adequate method of interpretative-dogmatic matrix capable of guiding the new generations of magistrates, lawyers, civil servants of the public institutions and even politicians. The most alarming aspect is linked with the strong cultural resistance on the part of universities, which in a short time was also reflected in strong resistance from the judiciary.

If formally we have passed to a modern law, respect for human rights and democracy, in practice we have remained anchored to a traditional approach of the law, which has not been able to evolve and grasp the new and opposing legal profiles advocated by many years from the criminal systems of Western democracies.

\section{The Problem of Reference Models}

The subject of the criminal code and related problems highlights the issue of the level of cultural development of a country. In countries like Albania, the past cannot be neglected, strongly characterized by a Soviet conception of law, centered on the ideology of the class struggle. If until 1995 the criminal law represented a functional tool for the repression of political opponents, we cannot think that the mentality and the way of conceiving and interpreting criminal justice can change from one day to the next due to the mere fact that the reference text has changed. The adaptation of the system, which took place in a few years, to the principles of the rule of law and respect for fundamental human rights certainly highlights a considerable sensitivity of the legislator. However, it cannot be assumed that the mere modification of the legislative formant can lead to an effective intellectual change. Yet, in this new and different path started with the fall of the communist system, the Albanian legislator has concentrated his efforts in introducing within his own systems of legislative texts that it takes back - but it would be more appropriate to say translate directly the more advanced ones of western countries. However, the lack of an internal debate on these texts by the scientific community and the professional categories of reference has led to a progressive distancing of the legislation from the real problems felt by the protagonists of the legal reality.

In short, by resorting to foreign models for the expansion and improvement of the internal legislative framework, there has been a progressive departure from the legal context in which the new provisions must live.

And in this sense, the Albanian criminal code is emblematic: a cocktail of legal rules of heterogeneous origin which, upon the proof of the facts, proved unable to outline a correct legal framework with reference to a subject of the utmost sensitivity, such as the criminal law.

Of course, the identification of a reference model can represent an interesting, and sometimes even intelligent, option for the legislator. Moreover, the comparative analysis and study of other legislation certainly constitutes a moment of cultural and intellectual growth that can lead to significant benefits.

In any case, the issue remains on which is the best system or model to refer to as part of a reform process of the criminal code. On this point, we will try to give some of our indications in the rest of this paper.

\section{6. (Few) Advantages and (Several) Limits of the Albanian Criminal Code}

The criminal code of 1995 is dotted with few lights and many shadows. It is undeniable that it is an alien product compared to the previous Albanian experience (Pelissero, 2008). This is perfectly understood since the criminal code of 1977 was characterized by a clearly totalitarian ideology (Elezi Elezi, 2010).

In truth, we find many of the democratic principles - such as prohibition of analogue, 
offensiveness, guilt, etc. - fully affirmed in the 1995 code (Rossi, 2008). However, the work is contradictory: it lacks organicity, coherence and systematicity. While the general part looks more like a mixture of provisions of the Italian, French and German criminal codes (and consideration of the mediation provisions, typical of the systems of northern Europe) the special part is similar to the French code, although the different classification of crimes.

However, merit should be given that, at least on paper, the cardinal principles of modern criminal law are found both in the Constitution and in the Albanian criminal code (Belfiore, 20o8). Article 29 of the Constitution, for example, states that "no one can be accused or found guilty of a criminal work, which is not foreseen as such by the law at the time of its realization". Article 2 of the Criminal Code also states that "no one can be criminally punished for a work that was not previously expressly provided for in the law as a crime or offense".

There is no doubt that the sentence expressly recalls the contents of article 1 of the Italian criminal code of 1930. If, however, in Italy the use of the term "expressly" was the source for the dogmatic elaboration of the principle of determination, according to which the "crime" must not, nor can it, be only formally provided for by the law, but it is also necessary that the latter clearly determine - that is "expressly" - what it is intended to incriminate, which cannot be other than a fact, in the Albanian criminal code such activity is lacking. Insights into the doctrine are lacking; there is a lack of valid proposals both in reconstructive-interpretative terms, and in a critical key, by the jurisprudence of both merit and legitimacy.

Moreover, the code already in the opening begins with an anomaly: it speaks in general of "criminal work" to be understood as a synonym of crime, without however specifying what is meant by a crime. What are the limits within which the legislator can insert "criminal works" within the legal system, it is not known. A necessary and obvious clarification (up to a certain point) is that we must deal with facts foreseen by the law as a crime; from the Albanian perspective, it does not seem to be a recent clarification that, the previous communist-style code of 1977 , generally provided for the term "criminal work" released from the fact; by leveraging the obscurity of the concept of "criminal work", mere manifestations of thought were also punished (the reference goes to crimes of agitation and propaganda) or conduct not expressly regulated by the legislator.

Therefore, already on the side of the reference object of the criminal law, the code was born badly; the key assumption is missing, namely that the object of attention for criminal law is made up of facts intended as human events appreciable externally and not mere manifestations of thoughts; facts which, moreover, must be offensive to legal assets to which the company attributes and recognizes an important and shared value and which therefore makes them worthy of protection on the criminal side. Only in this way, in fact, can the intervention of the legislator aimed at producing the criminal law be considered justified and legitimate.

Now, these considerations that seem obvious, clash with the legal backwardness that characterizes Albania, in whose jurisprudential or doctrinal elaborations, except for rare and lost items in the doctrine, there is no reference to the concept of legal good as well as to the principle of necessary offensiveness; the lack of in-depth scientific or practical nature has often led jurisprudence to punish conduct despite being totally devoid of an effective charge damaging to the legal good.

Here the point is not so much about the structure of the code, but the conception of criminal law by the Albanian jurists, still too tied to the traditional schemes of the author's criminal law and the social dangerousness of the cases. If the latter is still understood as the fulcrum of the system - in the face of the opposite concept of legal property as the true and only object of protection by criminal legislation - this cannot be attributed to the structure of the code but to the cultural humus in which it is himself lives.

Returning to the code, Article 4 of the Albanian criminal code is certainly to be appreciated. It provides that ignorance of the criminal law does not excuse, except in the case of unavoidable ignorance. The law seems to follow the article 5 of the Italian criminal code after the intervention of the Constitutional Court in 1988, with the famous sentence no. 364 .

Indeed, in terms of guilt, the Albanian criminal code would seem to take a step forward. Article 
14 (1) sanctions the principle of guilt in general, without guilty no one can be punished, while Article 14 (2) provides that the two forms of guilty are willful misconduct and guilt (pakujdesi). If we carefully analyzed the provision, it emerges that the current code adheres to the so-called normative theory of guilt and not that of guilt in the psychological sense. But the question is: in what terms have doctrine and jurisprudence interpreted this norm?

Another case. The provisions on the attempt seem to resume those provided by the German legislator in Articles 23 where for this form of manifestation of the crime the reduction of the penalty is provided as merely optional since the guilt for the crime attempted is, as a rule, considered to be entirely equivalent to that for the crime committed (Palazzo - Papa, 2005). However, the question just posed comes back: is the Albanian code inspired by the same conception of guilt endorsed by the German code? Moreover, have the Albanian doctrine and jurisprudence analyzed this norm in the correct perspective? Furthermore, have the Albanian doctrine and jurisprudence ever refered to the interpretations proposed by the jurists of the legal system from which the norm is taken?

The consequence in practical terms is: excessive discretion of the judiciary in the imposition of sentences in attempted cases, without the same being followed by a solid legal argument, as it is instead in the German judiciary system.

The Albanian code includes actions and omissions among the forms of manifestation of the conduct. However, following in the footsteps of the French code, it lacks a provision that regulates the crime of omission and especially the source of the legal obligation, but contrary to the more noble code which inspires it, it does not present a large number of hypotheses of omissive responsibility. The consequence is that, in absence of a regulatory referent, many omissive facts remain exempt from any form of liability.

\section{Some Further Examples of the General Part That Highlight the Criticisms That Characterize the Current Criminal Code}

Articles 48, 49 and 50 Albanian criminal code govern common mitigating and aggravating circumstances. The discipline follows articles 61 and 62 of the Italian criminal code. Even Article 49 identifies the generic extenuating circumstances provided by Article 62 bis the Italian criminal code. Except that, in the Article 47 Albanian criminal code establishes that the extenuating and aggravating circumstances must be used as a parameter for the judge in establishing the penalty between the maximum and minimum provided by the incriminating law. On the one hand, there are the circumstances, as codified in the Italian code, at the point of application of the same, the German discipline is followed. Although the latter does not provide for a general regime in terms of circumstances for individual crimes, but autonomous circumstantial hypotheses. In short, in Albania, the criminal code, in addition to providing for individual circumstantial hypotheses, also includes provisions of the general part that codifies the so-called common circumstances, which, however, can only be relevant for the purposes of grading the sanctioning response within the minimum and maximum legal provisions envisaged for the individual case.

The system of attributability of the circumstances is also problematic. On this point, the Albanian criminal code is silent, while the jurisprudence favors their objective application (whether it is mitigating or aggravating circumstances), regardless of the knowledge / knowability of the same by the agent.

In the face of this, however, there are many rules on the special part that are constructed in purely objective terms and do not leave the possibility of an effective scrutiny of guilt. Many are forecasts aggravated by the event, which is objectively blamed for the mere fact of having come into existence; for example, objective situations related to the age of the victim, or situations that cannot be objectively known by the offender are in any case sources of responsibility. Then, as mentioned, the lack of a regime of imputation of circumstances makes their application to the offender almost automatic regardless of whether they are known or knowable by the same.

The lack of discipline on error is considered by many as problematic. It probably is if analyzed 
from the perspective of Albanian law. Probably with small dogmatic efforts the doctrine could reach the realization of a discipline in this regard despite the lack of indications from the legislator; and this without forcing the rules or by accessing interpretations in malam partem, but by means of a careful exegesis of the provisions governing the notions of willful misconduct and negligence. But if there is no theory on willful misconduct, its object and assessment, how can one expect to build a valid theory on the concept of error (lajthitje)?

\section{Some Problematic Examples Can be Found in the Special Part of the Albanian Criminal Code}

With particular focus on the provisions of the special part of the code, the problems are multiple. The disrespectful provisions of the cardinal principles of modern criminal law, such as legality and guilt, make up a large part of the entire code system: just think of Article 134 on the subject of theft: the law does not indicate what the punishable conduct is but it limits itself to general notion of "whoever commits a theft is punished". Of course, it should not be overlooked that at a European level a jurisprudence is being formed more and more for which the knowability of the contents of the law is given not only by the written source but also by the jurisprudential one, but frankly this cannot modify the negative opinion on the provisions of the special part of the Albanian criminal code: many of them totally omit to describe the punishable facts, with evident vulnus of the principle of determinacy.

Another emblematic rule capable of providing a sufficient and bleak picture of the Albanian criminal code is that of infanticide (Article 81 Criminal Code); the phenomenon is punished as a contravention (Bozheku, 2012) and this already denotes a lack of sensitivity towards fundamental concepts of the general theory of crime such as the legal good, offensiveness, etc. Many examples such as those just highlighted can be done.

Moreover, also the special part of the current Albanian criminal code is a cocktail of provisions taken here and there by different legal systems, very different from each other both in terms of content and legal tradition. The result is an incomplete, contradictory and, in many ways, obscure product. Its practical application is proof of this: the point of law, which should involve the magistrates more, is hardly ever explored on an argumentative level (Jahjolli, 2014). Often there are gaps in style expressions that take up basic university explanations of the rules without, however, an intrinsic evaluation and interpretation of the same is carried out both in a dogmatic and systematic key: very rarely are jurisprudential pronouncements in which the historical fact is placed at all within the standard and therefore interpreted in depth in a correct way.

On closer inspection, as reported for some time, the need to create a new code can no longer be postponed.

\section{Albanian Doctrine and Jurisprudence Between Transition and Legal Tradition}

The reading of current legislation, doctrine and above all of Albanian jurisprudence betray an untrue picture on the history of Albanian criminal law.

If one were to examine the texts of the recent past, one would come across - in a very unexpected way, at least given the dramatic situation in which the current Albanian criminal science lives - in juridical productions of excellent value. The text of the laws, the doctrine, and the case-law up to the early 9os, from a technical-juridical point of view, are certainly appreciable; and this to the extent that they were characterized by a total and enviable coherence with the founding values of the society in which they lived. The doctrine of the time succeeded in the not easy task of translating the Marxist-Leninist ideology of the time into legal terms and which formed the basis of the morality of society. If we were to analyze in historical key institutions, which are divorced from us today, such as the social dangerousness of the author or the class struggle and the dictatorship of the proletariat (positioned at the center of the entire system), we can come to the conclusion that criminal science 
in Albania, from 1944 to 1991, had achieved a considerable degree of emancipation.

Obviously, the conclusion must not be exploited and read out of the context of reference. We do not want to exalt the historical period of communism here, but only to demonstrate that in that period Albanian criminal law was of a high level because it was able to be consistent with the dominant ideology that constituted its presupposition.

Therefore - and this is strongly reiterated to resolve immediately any impulse aimed at exploiting what has just been highlighted - the judgment just expressed it should not be read in a political key, but rather on a technical-legal one: Albanian jurists were able to produce valid and consistent laws and interpretations for the time.

The question is, what about today? The 1990s marked a radical change in the Albanian society; not only has there been a transition from communism to democracy, but also a radical change in values and in the dominant morality.

Common and shared values, such as the collectivity and the supremacy of the weakest (the proletarians) over the strongest (the bourgeois classes), have given way to new values based on meritocracy, the free market, etc.

On the criminal law front, however, at least in the opinion of the writers, there has been a step backwards. The legislator has begun to coin new rules, capable of governing the new socio-legal context. Here, however, we witnessed a new and unprecedented figure for Albania. While up to 1991, also considering the closure of the country, it was local jurists who dealt with the production of legislation, with the advent of democracy the mechanism failed: we increasingly relied on super experts from different parts of the world, because they were considered more experienced than the local ones, or because the local ones represented a ruling class too close to the past.

This has led to compromise laws, such as the criminal code, which is affected by the "hand" of jurists from different parts of the world. The same can be said, then, of the criminal procedure code of 1998, nothing more than a miniature reproduction (the institution of the preliminary hearing was not foreseen) of the Italian criminal procedure code of 1988.

Other factors should not be overlooked, such as the precariousness of the ruling class: since the early 1990s there has been a continuous change in the management class for reasons related to factors of a political nature, but also to phenomena of clientelism, nepotism and corruption. Above all in the ministries the continuous change of personnel has not allowed the formation of a serious and valid ruling class.

Not dissimilar phenomena have also characterized the university front and the judiciary. With reference to the first, the new class of professors has not shown itself capable of pulling the country from a physiological phase of legal transition to that of consolidation. Two phenomena occurred, however very contradictory: the only subjects who continued to play an important role in the interpretation of the criminal code were the jurists trained during the previous regime. Their work has been and is certainly appreciable, especially if it is evaluated in terms of efforts to try to understand and illustrate the innovations proposed by the new system. At the same time, however, this also represented a limitation since, given their formation strongly influenced only by the ideological approach, it was not possible to develop a criminal dogmatic in step with the times, able to compare with that of other countries Europeans. This has led, on the one hand, to a mental closure, due to the lack of comparison - and above all of knowledge - of the most recent legal interpretations in the field of criminal law and, on the other, to the creation of a distorted method of training local jurists. As proof of what has been said, it is sufficient to read the contributions of doctrine and texts in circulation in Albania: the authors limit themselves to explaining the provisions through a mere repetition in "prose" of the individual articles of the law, without carrying out particular systematic or dogmatic in-depth studies. At the most, on some occasions it is limited to a free criticism of the legislator, the rules he coined, the gaps that characterize the legal texts, without any particular analysis on a coherent interpretation of the texts in force.

In this regard, the criminal code is proof of this. Its analysis is very poor; often the authors limit themselves to illustrating the single norms. The works of the most famous authors with a deep 
seriousness and knowledge of the criminal law in force during the old regime, suffer from the influence of some typical concepts of that period. For example, the concept of social dangerousness is still central in the analysis of the criminal legal institutions. Although this concept is not included in the code, it is used as a central element for the interpretation of the individual provisions of the special part, where, conversely, the concept of legal good is proposed only by very few items in the doctrine. The same can be said in relation to the method of analyzing the structure of the crime: local jurists are particularly influenced by the Soviet method of unitary analysis of the crime or, at most, they refer to the classic Carrara dichotomy according to which the crime is composed of two elements, the objective and subjective element, whereas, conversely, the classic themes of bipartition and tripartition are neither known nor taught. The same we can say for the principle of guilty: local jurists limit themselves to Carrara's classic definition of vis morale and the psychological conception of guilt, while, with rare exceptions, there is no adequate knowledge of the theory of guilt in the normative sense. No in-depth analysis, then, is made regarding the structure of willful misconduct, negligence, with regard to the involvement of persons in the crime, etc.

Then there is a further fact: the new class of scholars is still too immature and too influenced by the previous method of analysis; moreover, the new jurists often do not find the same level of seriousness and constancy as in those trained in the previous period. This represents not only a paradox, but also constitutes a truth that cannot be overlooked. The writings of local jurists are more often than not aimed at the achievement of academic qualifications, while there is not sufficient sensitivity in understanding the contributions of doctrine for the dissemination of knowledge and therefore support for the improvement of preparation not only from part of the students, but also of the legal practitioners (prosecutors, judges). In such a context it is clear that the influence of the traditional conception of criminal law can only be dominant.

Therefore, the lack of openness towards a modern method of analysis of criminal law constitutes a limit of a cultural nature due both to the transition and to the difficulties of freeing oneself from tradition; the latter continues to play a significant role in a legal environment that finds it particularly difficult to open up to a modern and democratic conception of criminal law. On the practical side, this translates into a backward and insensitive criminal justice towards citizens' guarantees.

It is true that the Albanian criminal code has serious structural deficiencies, but it is also true that the lack of any legal operation on the part of doctrine and jurisprudence aimed at compensating for them, as far as possible and without leading to the analogy in malam partem, delivers a seriously compromised criminal justice since the guarantees for the citizen represented by the rules of the code in their correct and in-depth interpretation do not work. The criminal provisions are applied automatically and superficially, compromising the principle of mandatory nature. Indeed, prima facie, this principle is respected by the magistrates, but, in truth, the lack of in-depth study of the concepts expressed in the general part of the code means that the sentences are characterized by a profound superficiality and lack of motivation, a circumstance that favors the arbitration of the judge.

It is clear that where there is arbitrariness, many problems accrue. If - in the past tradition - the arbitrariness of the magistrate was favored by ideology, and therefore the reference to empty formulas such as the class struggle and the dictatorship of the proletariat constituted the means by which to fight the enemies of the old communist system and therefore guarantee the existence of the same, today, however, the arbitrariness of decisions - due, on the one hand, to the preservation of an inherited mindset and on the other hand by the lack of inclination towards knowledge of the cornerstones of modern criminal law - irremediably favors the phenomenon of corruption within the judicial system. There is a suspicion - it is hoped not well founded - that sentences that are manifestly arbitrary and have no legal basis, in the absence of consolidated control mechanisms both by the higher judges (Courts of Appeal, High Court) and of the doctrine, which does not carry out at present, neither a sufficient critical function towards jurisprudence nor technical-reconstructive and therefore prepositives of the law, not only do not cause a sensation but even serve the phenomenon of corruption. 
In fact, one gets the impression that the lack of interpretative paths aimed at providing a systematic and coherent vision of the current code, as well as the lack of conceptual and dogmatic insights by doctrine and jurisprudence, over the years, as well as finding support in the laziness of the new scholars, has been transformed into a system - tacitly shared - through which to encourage corruption within the justice system, transforming the latter into a sort of paid justice for the prerogative of the richest and most especially of organized crime.

One gets the impression - hopefully it is a wrong impression - that the Albanian jurist often hides from ignorance. To be better understood: with reference to the first side, an important characteristic of a character or - if we want - anthropological nature should not be ignored: by considering that Albanians are extremely proud (due to their historical and social conformation) it is difficult for them to admit their own shortcomings and their own ignorance. The feeling of shame is so widespread and felt that we tend to flee and hide from ignorance: the judgment of others can be so heavy that, for a shared question of personal, social and environmental serenity, Albanians tend to conform and see in tradition a tool through which to overcome one's ignorance and therefore one's personal feeling of shame. From this point of view, it is clear that it is much more convenient to ignore everything new in favor of tradition.

This also explains why the doctrine lacks valid debates among scholars, which seems almost afraid to confront the opinions of others. If anything, there are criticisms, these are on a general level, but they never go into an analysis of the ideas of others. Proof of this is the scarce manual production: it would seem that, once an author has written on a specific topic, it becomes his exclusive prerogative. Both in order not to get involved and therefore to avoid having to face the judgment of others, and in order not to expose themselves to criticism, Albanian scholars rarely increase their handbooks on topics that other colleagues have written. And if this should happen in some rare case, the thought of the colleague who has already written on the subject is not in the least taken into consideration, it is not mentioned in any way, but rather is deliberately ignored, almost as if they were afraid to recognize the other people's thoughts. And this not, as is often thought, because of one's own exasperated self-esteem, but rather for the reverse reason: by deliberately ignoring the thoughts of others, one has a freer conscience and therefore one frees oneself from the idea of a possible negative judgment on own work by the community, in the context of a judgment of comparison with the work of the colleague. Moreover, by pretending to ignore the ideas of others it is much easier to avoid a comparative judgment with one's own. Therefore, in the opinion of the writers, which is based on the knowledge not only of the law but also of the culture and mentality of the Albanian citizens, the "traditional" sense of shame (which constitutes the other side of the feeling of "pride", which characterizes the people of Albania) that has gripped the country for centuries represents an important limitation for the development of its law.

More delicate is the other issue mentioned earlier, namely that, at times, Albanian jurists probably find it convenient to hide in ignorance. There is a feeling - hopefully, the authors are wrong - that often, especially a good part of the Albanian judiciary, deliberately favors a scarce analysis and deepening of the law. In a superficial and self-referential legal context, controls are inevitably laxer; the level of arbitrariness of judgment is much higher; the possibilities of transforming justice into an instrument from which to derive illegitimate wealth is much higher. The fact is that for many years the Albanian magistrates have interpreted their function in a purely personal key, establishing themselves as holders of public power administered in an exclusively private form; by exploiting their professional investiture they have for years drawn illicit profits, at the same time transmitting to public opinion the idea of a justice based on injustice and arbitrariness, where reason is not on the side of those who have the law on their side, but who is able to pay the judge better. In such a framework, it is perfectly understandable why the European Union has placed justice reform on Albania as the first condition for entering Europe.

Well, in the light of what has been highlighted so far, there is no one who does not see how the problem of the Albanian criminal code is not linked only to its contents, but to the context in which it lives, to its (poor) interpretation by the current class of jurists (both theoretical and practical). So, 
what actions should be taken so that the reform of the criminal code can lead to satisfactory results?

\section{Some Observations for a Correct Implementation of a "New" Albanian Criminal Code}

As mentioned, the reform of the criminal code represents one of the most complex challenges for a legislator, as it is a question of providing the rules on which civil coexistence is based. Moreover, the criminal code when it automatically punishes certain behaviors and protects the values deemed indispensable for the legal system. When a criminal law punishes an event, the message that is transmitted to citizens is that that particular fact is harmful to society as it is capable of damaging a value it shares; therefore, the members of the society are exhorted to refrain from committing similar acts, otherwise they will be subjected to the punishment foreseen for those who commit them.

To give an example: when in Article 76 Albanian criminal code the legislator punishes anyone who commits a murder, the rule automatically protects a primary good for the community, that is life. This is the protected juridical good and it is around this that the legislator must build the rules on murder. Through this rule, the message that the legislator sends to citizens is to invite them not to cause the death of their fellow men, otherwise they will be subjected to a criminal sanction in relation to what they have committed. Each criminal law therefore has its own referent in the sense that it aims to protect a specific legal asset (e.g., life, property, environment, economy, health, etc.). And then we can agree and conclude that the criminal code is nothing more than a book that preserves and protects the values of a particular society; and this is achieved in the negative through the description of conduct antithetical to these values and therefore considered worthy of sanction.

If this is the function of a criminal code, it should not be overlooked that it lives within a specific social context. In the case of the Albanian criminal code, it lives and applies to faults committed in the territory of the Republic of Albania. And so, for its drafting it is important that the degree of culture of the population and above all the Albanian jurists is considered.

As a result, it is clear that the new Albanian criminal code must not only be drafted in such a way that it is in line with European standards, but should also be accompanied by a massive teaching activity of Albanian lawyers. in relation to modern methods of analysis and interpretation of condictio norms.

To this end, a double path could be envisaged. On one hand, directly involve the scholars of criminal law (both theoretical and practical) in the drafting of the rules and not entrust this only to the technicians of the ministries supported by international experts, and on the other hand start training courses for local jurists. In this perspective, it is desirable that the formulation of the criminal laws is not limited to a translation activity of the provisions belonging to foreign codes, but it will be necessary first of all a broad reflection on the contents of the provisions that will be inserted in the text, on their correct interpretation both systematic and conceptual and above all on the repercussions they may have on the system.

This is one of the main challenges proposed by the reformulation of the criminal code. The latter must not only be in harmony with the constitutional principles and European standards dictated by articles 6 and 7 ECHR, but - above all - must be the result of an elaborate comparison operation between local and foreign jurists able to grasp the pitfalls that the realization of the new text can propose precisely with reference to the principles now shared at the European level.

In other words, during the reform of the code it would be advisable that every provision that will be implemented be subjected to a guarantee check by the jurists, to verify whether, on the occasion of its interpretation, it responds at least to the principles of certainty, offensiveness and guilt which are also the basis of the European Charter on Human Rights.

Certainly, we must avoid the mistakes of the past: we must avoid that the legislative activity of the new code is limited to the translation of foreign provisions, while an extensive comparison between scholars of domestic criminal law will be appropriate. This is not meant to argue that compilers do not have to refer to models from other countries, but that it will be necessary to evaluate well the model to be taken into consideration if it fits the degree of development to Albanian 
society, first and foremost to that of scholars and practical practitioners in the field of criminal law; just as it will be important not to mix provisions belonging to heterogeneous models.

On a concrete level, it is believed that one should opt for a code model that contains a significant number of rules, some also aimed at the sole purpose of clarifying certain concepts to the jurists who will analyze the work. This aspect - at least in the opinion of the writer - is particularly delicate: this especially if we consider that the modern codifications (think of the Spanish or German one of the 1990s or the reform projects of the Italian criminal code) tend to provide for a minimum number of provisions, especially as regards the general part.

Well, we are firmly convinced that this is a path that cannot be validly proposed in Albania. The current code was designed precisely in this perspective and the results are what they are; and as evidenced they are not at all encouraging. If in other countries, for centuries doctrine and jurisprudence have played a decisive role in the coherent and logical interpretation (and sometimes harmonization) of the provisions of the law, this is not the case for Albania. As highlighted, from a methodological point of view, the links with the way of thinking of the past are still very strong, there is no significant awareness and knowledge of the current - and very high - level of scientific studies in the criminal law sector at a European level, there is a sense of shame in facing interpretative paths based on modern methodological bases.

Therefore, it would be appropriate for the new code to specify as much as possible the key points and concepts around which the ideology of modern criminal law revolves. To give an example, it is not sufficient for the Albanian legislator to indicate that the two forms of guilt are willful misconduct and negligence (current article 14 Criminal Code) and then regulate the related concepts, but it is necessary that the same establish the elements of the case which must be the object of willful misconduct, the various forms of willful misconduct (intentional, direct, indirect, specific, impetuous, intentional, etc.) in such a way as to give certainty to individual concepts.

It is of the opinion that in order to ensure correct application of the Albanian criminal code, it is necessary to go through the creation of a product nourished by concepts and notions capable of also carrying out a training function for the operators of criminal justice.

It is clear that in order to do this, the code should run counter to the other European codes. However, there are no elements to believe this path cannot be shared, especially if the problems highlighted so far are taken into consideration. Moreover, the current (inadequate) state of knowledge of criminal law on the part of local jurists cannot be overlooked; indeed, taking a cue from this aspect it is important that the choices to be made are respectful of this data and therefore aim to improve it. Otherwise, there is a serious risk that the implementation of a new code will not improve the situation of justice in Albania, but even generate further chaos in an already particularly chaotic situation.

But the real keystone can be found if, alongside the intervention on the code with a view to creating a new one, serious efforts are made to improve the level of knowledge of Albanian jurists. This is one of the most delicate issues, but also one of the most neglected by diplomatic representations, both European and American, in Tirana. Corruption and the links between the judiciary and organized crime cannot be fought without striving hard to fight ignorance.

\section{Conclusions}

A major cultural reform must be developed that sees the entire class of Albanian lawyers personally involved, from professors, lawyers, magistrates, researchers, civil servants, policemen, university students; reform that must aim, first of all, to overcome the sense of shame that grips the operators of the law and, secondly, to form them from the foundations. In this perspective, it is important that the method of analysis, systematic and dogmatic-conceptual interpretation of the individual rules and the entire discipline is taught; debates between jurists, round tables, conferences and above all the continuous creation of authentic and concrete scientific works in the form of sentence notes, articles, monographs and commentaries should be encouraged.

This is probably the real and most delicate challenge that the representatives of the 
international organizations in Albania are called to understand and face; otherwise, there is a risk that the new criminal code in terms of contents and editorial technique is perhaps better than the previous one and this however continues to be inadequate and unable to offer valid answers to the needs of justice of the Albanian people.

In short, either the society aims to build a solid and prepared class of jurists (primarily university professors) capable of spreading a correct and in-depth knowledge of criminal law or otherwise the new code, however well done and rich in content it may be (but this applies more generally to the entire reform of justice), it will be destined to remain a work of pure form but not applicable in various case-law.

\section{References}

Agaçi, E. (2017). Novità del sistema di giustizia in Albania. Vetting e altre misure per il restauro della fiducia in pubblico, in La riforma costituzionale ("strutturale") del sistema della giustizia nella Repubblica d'Albania, edit from Bozheku-Spangher-Hoxha, Edizioni Nuova Cultura, Rome.

Belfiore, E. (2008). La disciplina dell'ignorantia legis nel codice penale albanese alcune considerazioni, in Il codice penale Albanese, a cura di Vinciguerra, Cedam, Padova.

Bogdani, M. (2008). Fighting Corruption and Organised Crime in Albania Through SPAK authirities noveltieson Costitutional and Legal approach in reflection of best international standards and practices in La riforma costituzionale ("strutturale") del sistema della giustizia nella Repubblica d'Albania, edit from BozhekuSpangher-Hoxha, Edizioni Nuova Cultura, Rome.

Bozheku, E. (2012), L'infanticidio. Spunti e rilievi di parte generale, Jovene, Napoli.

Bozheku, E. (2013). Le problematiche del sistema penalistico albanese: un panoramico sguardo d'insieme, in AA. VV., Scritti in onore di Alfonso M. Stile, Edizioni Scientifiche Italiane, Napoli.

Bozheku, E. (2014). Ide, mendime dhe reflektime lidhur me nevojat dhe masat që duhet dhe mund të merren në kuadrin e reformimit të sistemit të drejtësisë - veçanerisht asaj penale - në Shqipëri, in Illyrius, 4.

Bozheku, E. (2014). Le problematiche del sistema penalistico albanese: un panoramico sguardo d'insieme, in archivio penale (web), I.

Bozheku, E. (2016). Chiose a caldo sulla riforma costituzionale del sistema giudiziario in Albania, Illyrius, 7 (II).

Bozheku, E. (2016). La riforma costituzionale ("strutturale") del sistema della giustizia nella Repubblica d'Albania, in diritto penale contemporaneo.

Bozheku, E. (2017). Alcune osservazioni sparse sul progetto di riforma del codice penale della Repubblica d'Albania, in La riforma costituzionale ("strutturale") del sistema della giustizia nella Repubblica d'Albania, edit from Bozheku-Spangher-Hoxha, Edizioni Nuova Cultura, Rome.

Elezi, I., Elezi, E. (2010). Zhvillimi i mendimit teoriko - juridik shqiptar, Shtepia Botuese e Librit Universitar, Tirane, 2010.

Elezi, I., Elezi, E. (2010). Histori e se drejtes penale, Shtepia Botuesee Librit Universitar, Tirane.

Fondaroli, D. (2008). Appunti sulla confisca nel codice penale della Repubblica d'Albania, in Il codice penale Albanese, a cura di Vinciguerra, Cedam, Padova.

Jahjolli, G. (2014). Problematikat e Sistemit penal dhe atij procedural penal në Shqipëri, in Illyirius, 4.

Liguori, H., Hoxha, A. (2017). La riforma del codice di procedura penale del sistema giudiziario in Albania. I procedimenti speciali: spunti di riflessione, in La riforma costituzionale ("strutturale") del sistema della giustizia nella Repubblica d'Albania, edit from Bozheku-Spangher-Hoxha, Edizioni Nuova Cultura, Rome.

Palazzo, F., - Papa, M. (2005), Lezioni di diritto penale comparato, II ed., Giapicchelli, Torino.

Pelissero, M. (2008). I reati politici nella codificazione penale albanese, in Il codice penale Albanese, a cura di Vinciguerra, Cedam, Padova.

Pittaro, P. (2006). Il codice penale albanese: un'introduzione, in Dir. pen. XXI sec..

Qeleshi, J., Skenderaj, K., Mengjesi, S. (2017). Prosecution under the new regulation in Albania, in La riforma costituzionale ("strutturale") del sistema della giustizia nella Repubblica d'Albania, edit from BozhekuSpangher-Hoxha, Edizioni Nuova Cultura, Rome.

Rossi, A. (2008). Note sugli illeciti penale dell'economia nel sistema del codice penale della Repubblica d'Albania, in Il codice penale Albanese, a cura di Vinciguerra, Cedam, Padova.

Spangher, G. (2017). Brevissime considerazioni sulle modifiche del sistema giudiziario in Albania, in La riforma costituzionale ("strutturale") del sistema della giustizia nella Repubblica d'Albania, edit from BozhekuSpangher-Hoxha, Edizioni Nuova Cultura, Rome. 